\title{
EFFECTS OF VARIOUS WATER LEVELS AND LATERAL SPACING ON THE YIELD AND QUALITY OF DRIP-IRRIGATED COTTON (GOSSYPIUM HIRSUTUM L.) UNDER ARID CONDITIONS
}

\author{
TARI, A. F. ${ }^{*}{ }^{*}$ ÇOŞKUN, Z. ${ }^{2}-$ OdABAŞIOĞLU, C. ${ }^{3}-$ AKIN, S. $^{1}$ \\ ${ }^{I}$ Department of Agricultural Structures and Irrigation, Agricultural Faculty, Harran University, \\ Şanluurfa, Turkey \\ ${ }^{2}$ The General Directorate of State Hydraulic Works, Çankaya, Turkey \\ ${ }^{3}$ Department of Field Crops, Agricultural Faculty, Harran University, Şanliurfa, Turkey \\ *Corresponding author \\ e-mail:aftari@hotmail.com
}

(Received $12^{\text {th }}$ May 2021; accepted $12^{\text {th }}$ Aug 2021)

\begin{abstract}
A field experiment involving cotton (Gossypium hirsutum L.) was conducted for two years to investigate the effects of deficit irrigation on seed cotton yield, fiber quality, and water productivity in Turkey. The main plots featured various drip line spacing, and the sub-plots included four irrigation levels based on class A pan evaporation in Turkey. Crop evapotranspirations were found to range from 585 to $1028 \mathrm{~mm}$ and from 601 to $1074 \mathrm{~mm}$ in consecutive years. Seed cotton yields ranged from 239.0 to $616.3 \mathrm{~kg} \mathrm{ha}^{-1}$, and the analysis of variance showed the presence of the statistically significant $(\mathrm{p} \leq 0.01)$ effects of irrigation levels on crop yield. The drip line spacing was effective for the yield only in the second year $(p \leq 0.05)$. Employed limited irrigation affected ginning outturn significantly $(p \leq 0.01)$ in both years. The results indicated that reduction in irrigation water did not have a significant effect on most fiber quality criteria. On the contrary, significant differences were observed for the leaf area index (LAI) traits of the treatments, and these reached the highest value approximately 100-110 days after planting. However, water productivity (WP) and irrigation water productivity (IWP) did not show significant differences among the limitations of irrigation water levels.
\end{abstract}

Keywords: cotton, irrigation levels, water productivity, leaf area index, drip irrigation

\section{Introduction}

The increasing urban and industrial demands for water, as well as the pollution of water resources have resulted in a decrease in the amount of water allocated to agriculture. In addition, global climate change, water constraint and drought cause serious problems for crop production all over the world (Katerji et al., 2008). Today, about $40 \%$ of the world's population suffers from water shortages (Steduto et al., 2012), but only $25 \%$ of agricultural land can be irrigated due to a lack of water resources. Turkey is one country that will face severe water shortages in the future.

Agricultural lands in Turkey are located in the arid and semi-arid climatic zones, so it is not possible to cultivate most summer crops without irrigation. Southeastern Anatolia (SEA) of Turkey is very hot and dry during the summer. Therefore, irrigation cannot be used for crop production. However, this region, where this study was carried out, is one of the most important agricultural zones in Turkey. Specifically, Harran Plain is the most important cotton-growing area, with cotton making up $85 \%$ of all plant patterns. 
Cotton is the main crop grown in arid regions of SEA under irrigation. The region is suitable for cotton cultivation due to its favorable climatic condition. In addition, cotton's economic return is higher than those of any other crops the region. Cotton seed can also be used for livestock feed and for edible cotton oil extraction in this area. All in all, cotton cultivation carries significantly higher return and an important crop in semiarid regions, where it represents a significant source of income for both large- and small-scale farms (Papastylianou and Argyrokastritis, 2014). Mechanization is common in cotton agriculture, but a significant amount of manual labor is still employed. Along with the yield of cotton, its quality is of great importance. Genotype, weather conditions, farmer practices, fertilization, irrigation management, environment, and the interaction of genotypes by environments all influence cotton fiber quality parameters (Campbell and Jones, 2005; Bilalis et al., 2010).

The high irrigation water requirement of cotton (Cetin and Bilgel, 2002; Chapagain et al., 2006) depending on the climate conditions have resulted in considerably important irrigation and environmental problems in this region. Furrow irrigation is generally practiced in the plain; however, irrigation efficiency is very low due to a lack of land leveling coupled with farmers' habits. In addition, the charging of irrigation water is based on the irrigated area rather than on the amount of water used. This is another important reason for the lower water productivity in SEA. The lower level of water productivity in SEA has resulted in significant problems with the sharing and distribution of irrigation water on the plain. In addition, the overirrigation of cotton leads to excessive vegetative growth and causes the leaching of plant nutrients from the root zone. Furthermore, increased costs of chemical fertilizer and contamination of groundwater supplies (DeTar, 2008) are other major problems. In addition, there is irrigation water shortage in the downstream part of the plain and cotton yield decreases significantly due to insufficient irrigation.

As mentioned earlier, as agricultural producers face insufficient water supplies, they need to conserve and sustainably use inadequate water resources (Cai et al., 2002). The decrease in water supply for cotton growth has caused researchers to focus increase in water productivity (Dagdelen et al., 2009a). The use of modern irrigation systems is one key solution to increase water use efficiency and/or water productivity. Irrigation modernization requires the identification of the most appropriate solutions to increase yield and income, as well as increasing water productivity and water saving (Darouich et al., 2014; Cetin and Kara, 2019). For example, it is important to use modern irrigation technologies, such as drip irrigation (Cai et al., 2002). Many studies in different regions of the world have showed that drip irrigation has provided many advantages compared to surface irrigation for cotton (Cetin and Bilgel, 2002; Ibragimov et al., 2007; Kang et al., 2012; Fan et al., 2018). With this method, a low amount of irrigation water is delivered through drip irrigation, and it results in both a higher yield and water efficiency (Kang et al., 2012). Drip irrigation has been recommended as a means of supplying most types of crops with uniform and frequent applications of water. These applications are adaptable for different topographic and soil conditions (Cetin and Bilgel, 2002). With drip irrigation systems, it is possible to achieve high water application efficiency and to reduce evaporation losses in arid regions, such as the SEA region, where the relative humidity is low. However, when transitioning from surface irrigation methods to drip irrigation, the farmers were initially reluctant. One of the main reason obstacles to the common adoption of drip irrigation is its relatively higher costs of investment and operation. The cost of the 
drip irrigation system increase as long as increasing the system's uniformity (Wilde et al., 2009). However, at present, the decreased water allocation and the increased energy and labor costs have resulted in the rapid employment of drip irrigation systems.

In many parts of the world, drip irrigation has been used for long time and it is practiced increasing the crop yield and reducing soil-surface evaporation as well as increasing irrigation water use efficiency (WUE) (Sampathkumar et al., 2013). Studies have reported that drip irrigation provides a high yield, quality, and water productivity level in cotton while saving irrigation water. However, the values obtained differed according to the climatic conditions and agricultural techniques applied (Ibragimov et al., 2007; Rao et al., 2016; Zhang et al., 2016).

Due to insufficient water resources, limited water is sometimes applied in irrigation. However, the reduction of irrigation water reduces dry matter accumulation, the boll weight, boll production, the leaf area, the number of nodes and of cotton (Gerik et al., 1996; Pettigrew, 2004; Mert, 2005; Kang et al., 2012; Chen et al., 2020). Leaves are associated with evapotranspiration (ET) and photosynthesis, and the measurement of leaf growth is an application used in most agronomic and physiological studies, as well as plant growth studies (Guo and Sun, 2001). The leaf area index varies depending on the number of leaves and the leaf size of the plant, with stress and nutrient deficiency negatively affecting it (Longnecker, 1994). Deficite irrigation can be applied in various ways. These are: (a) not irrigating during periods when the plant is not sensitive to water, (b) extending the irrigation interval, (c) excluding areas with low yield potential, or (d) reducing the amount of water by certain amounts each time.

In this study, the drip irrigation method was applied to cotton plants grown in arid climatic conditions for the growing season applying different irrigation levels. The aims of the study were (1) to assess the effects of various irrigation water levels and drip line spacing on the seed cotton yield, and (2) to establish leaf area index, the lint quality and water productivity.

\section{Materials and methods}

\section{Experimental site and climate}

This study was carried out in the growing seasons of 2014 and 2015 in the experimental fields of Harran University $\left(37^{\circ} 07^{\prime} 38^{\circ} 48^{\prime}\right.$ and $467 \mathrm{~m}$ above sea level) of Sanliurfa, Turkey.

According to the Aydeniz climate classification, the region is included in the arid climate classification (Bölük, 2016). Summers are dry (very low relative humidity, 10$15 \%)$ and very hot and, and winters are relatively cold and wet. The long-term annual average rainfall in the area is about $360 \mathrm{~mm}$, and the open-water surface evaporation is $1850 \mathrm{~mm}$. Winter precipitation continues until early spring, however, the distributions differ significantly from year to year. June, July, August, and September are the hottest and driest months, whereas January and February are the coldest months. In July and August, the daily maximum temperatures often exceed $40^{\circ}$ whereas the minimum temperatures seldom fall below $0{ }^{\circ} \mathrm{C}$ in the winter months.

The experimental soil is clay (USS 1954), and its infiltration rate is $9 \mathrm{~mm} \mathrm{~h}^{-1}$. It is characterized as being salt free and slightly alkaline. Some analysis results of of the soil profile are given in Table 1. The lime is about $8.80 \%$. In addition, the available water holding capacity of the 0 - to $90-\mathrm{cm}$ soil profile is $182 \mathrm{~mm}$. 
Table 1. Some physical and chemical properties of the soil in field trials

\begin{tabular}{|c|c|c|c|c|c|c|c|}
\hline $\begin{array}{c}\begin{array}{c}\text { Soil layers } \\
(\mathbf{c m})\end{array} \\
\end{array}$ & Texture & \begin{tabular}{|c|} 
Field capacity \\
$\left(\mathrm{g} \mathrm{g}^{-1}\right)$
\end{tabular} & $\begin{array}{c}\text { Wilting point } \\
\left(\mathrm{g} \mathrm{g} \mathrm{g}^{-1}\right)\end{array}$ & $\begin{array}{c}\text { Bulk density } \\
\left(\mathrm{g} \mathrm{cm}^{-3}\right)\end{array}$ & $\begin{array}{c}\text { EC } \\
\left(\mathbf{d S ~ m}^{-1}\right)\end{array}$ & pH & $\begin{array}{l}\text { Lime } \\
(\%)\end{array}$ \\
\hline $0-30$ & $\mathrm{C}$ & 0.357 & 0.220 & 1.36 & 0.671 & 7.3 & 8.51 \\
\hline $30-60$ & $\mathrm{C}$ & 0.363 & 0.211 & 1.47 & 0.744 & 7.4 & 8.77 \\
\hline $60-90$ & $\mathrm{C}$ & 0.357 & 0.220 & 1.47 & 0.753 & 7.4 & 9.19 \\
\hline
\end{tabular}

\section{Agricultural applications}

Cotton seeds were sown on 03 May 2014 and 01 May 2015 using a plot drill with $70-\mathrm{cm}$ row spacing and $10-\mathrm{cm}$ intrarow. The plant density was 142857 plant ha $^{-1}$ in both years of the research. In the experiment, the cotton variety of Stoneville 468 was employed as experimental material. The plot size was $25.20 \mathrm{~m}^{2}(6.00 \times 4.20 \mathrm{~m})$. However, during the harvest, the plot size was reduced to $14 \mathrm{~m}^{2}$, thus eliminating the border effect. Hand harvesting was practiced twice during both years. The first harvest was practiced at the ball opening stage of $80-90 \%$, and the second harvest was practiced after the remaining $10 \%$ of balls had been opened. Thus, the firsthand harvest was realized on 15 September 2014, and the secondhand harvest was realized on 16 September 2015. The second harvest was performed about three weeks after the first harvest was performed.

After the plant emergence, hoeing was done by machine and twice by hand. The plants in the plots were decreased, taking into consideration an intrarow spacing of 15$20 \mathrm{~cm}$. For fertilizing, $80 \mathrm{~kg} \mathrm{~N} \mathrm{ha}^{-1}$ and $80 \mathrm{~kg} \mathrm{P}_{2} \mathrm{O}_{5} \mathrm{ha}^{-1}$ were applied at planting. The fertilizer source was a compound fertilizer (20-20-0). Then, the remaining $\mathrm{N}$ was applied. It was split three times, with equal amounts of each being used via drip irrigation (Çetin and Akalp, 2019). In addition, total of $80 \mathrm{~kg} \mathrm{P}_{2} \mathrm{O}_{5} \mathrm{ha}^{-1}$ and $160 \mathrm{~kg} \mathrm{~N}$ $\mathrm{ha}^{-1}$ were applied as fertilizers. Some chemicals were applied against Empoasca sp. (active ingredients: \%20 Acetamiprid $10 \mathrm{~g} \mathrm{da}^{-1}$ ) and thrips (active ingredients: $100 \mathrm{~g} \mathrm{l}^{-1}$ Cyantraniliprole).

\section{Experimental design and treatments}

The experiment was conducted using split plots in randomized complete blocks with three replications. The main plots included various drip line spacings $\left(\mathrm{L}_{1}: 0.70 \mathrm{~m}\right.$ and $\mathrm{L}_{2}: 1.40 \mathrm{~m}$ ), and the subplots featured irrigation ratios based on different coefficients of Class A Pan evaporation ( $\mathrm{I}_{1}, \mathrm{I}_{2}, \mathrm{I}_{3}$, and $\left.\mathrm{I}_{4}\right)$. Thus, eight different irrigation levels were applied during the field study. The treatments are given in Table 2.

The water used for irrigation was received from deep wells. The water from the deep wells had low sodium content and medium salt. $\mathrm{p} E$ and class of irrigation water is 7.87, $0.72 \mathrm{dS} \mathrm{m}^{-1}$, and $\mathrm{C}_{2} \mathrm{~S}_{1}$ respectively. In addition, the control unit for drip irrigation was formed using hydrocyclone, a sieve filter, pressure gauges, a fertilizer tank, and valves. The filtrated irrigation water was delivered by a $75-\mathrm{mm}$ polyethylene pipe (PE) to the experimental site and was applied to the plots via 50-mm PE pipe lines. The diameter of drip lines was $16 \mathrm{~mm}$. Also, the drip line spacing was $0.70 \mathrm{~m}$ in $\mathrm{L}_{1}$ and $140 \mathrm{~cm}$ in $\mathrm{L}_{2}$. Drippers in the drip line were placed $33 \mathrm{~cm}$ apart and had a flow rate of $4 \mathrm{~L} \mathrm{~h}^{-1}$, and the selection of the drippers was based on the soil characteristics as described in Keller and Bliesner (1990). Furthermore, the operation pressure of the drip irrigation system was 1 atm. For the purpose of providing for the germination of the seeds, all of the 
experimental plots were irrigated two times with equal irrigation levels and with a small amount of irrigation using a sprinkler irrigation system. The drip irrigation system was installed following the second hoeing of the plots.

Table 2. Experimental treatments

\begin{tabular}{c|c}
\hline $\begin{array}{c}\text { Main plots } \\
\text { (drip line spacings) }\end{array}$ & $\begin{array}{c}\text { Subplots } \\
\text { (irrigation factors) }\end{array}$ \\
\hline & $\mathrm{I}_{1}\left(\mathrm{~K}_{\mathrm{p}}=1.50\right)$ (full irrigation) \\
$\mathrm{L}_{1}(70 \mathrm{~cm})$ & $\mathrm{I}_{2}\left(\mathrm{~K}_{\mathrm{p}}=1.25\right)$ \\
$\mathrm{L}_{2}(140 \mathrm{~cm})$ & $\mathrm{I}_{3}\left(\mathrm{~K}_{\mathrm{p}}=1.00\right)$ \\
& $\mathrm{I}_{4}\left(\mathrm{~K}_{\mathrm{p}}=0.75\right)$ \\
\hline
\end{tabular}

\section{Irrigation water applied}

The amount of irrigation water applied was calculated via multiplying the evaporation amount from the Class A Evaporation Pan based on various $\mathrm{K}_{\mathrm{p}}$ coefficients. Thus, the total amount of evaporation for each of the seven days was multiplied by considering various coefficients and crop cover percentages. The crop cover percentage was scored by measuring the width of the plant crown prior to each irrigation. The first irrigation was practiced when $50 \%$ of the available water in the 0 - to $60-\mathrm{cm}$ soil profile was consumed. All experimental plots were irrigated until the field capacity was reached during the first irrigation, whereas the subsequent irrigations were based on the requirements of the experimental treatments. The amount of water given to the plots was measured using a water gauge, and the amount of rainfall was obtained from the meteorological station in the experimental area (Ünlü et al., 2011). The equation in calculation of the amount of irrigation water is given below:

$$
I W=A \times E_{p a n} \times K_{p} \times P C
$$

where IW: the amount of irrigation water applied $(\mathrm{mm}) ; \mathrm{E}_{\mathrm{pan}}$ : the cumulative evaporation from the Class A Pan at each irrigation interval $(\mathrm{mm}) ; \mathrm{K}_{\mathrm{p}}$ : the coefficient used to obtain a different irrigation level; and Pc: the plant canopy cover (it was estimated by measuring whole canopies of five plants selected randomly from each plot throughout the irrigation season). The evaporation was measured using a screened Class A Pan located at the meteorological station near the experimental field.

The soil moisture in all experimental plots was monitored at a soil depth of $0-120 \mathrm{~cm}$ through the gravimetric method. The actual evapotranspiration was computed using the equation of water balance (James, 1988):

$$
E T c=I+P+D_{p} \pm R_{\text {off }} \pm \Delta S
$$

where ETc: crop evapotranspiration $(\mathrm{mm})$; I: the amount of irrigation water applied $(\mathrm{mm})$; P: the rainfall $(\mathrm{mm}) ; \mathrm{D}_{\mathrm{p}}$ : the deep percolation $(\mathrm{mm}) ; \mathrm{R}_{\text {off: }}$ the runoff $(\mathrm{mm})$; and $\Delta \mathrm{S}$ is the change in the moisture content at a root depth of 0-90 $\mathrm{cm}(\mathrm{mm})$.

Irrigation water productivity (IWP) and water productivity (WP) were calculated through the gauge effects of irrigation programs (Pereira et al., 2012). The equations are as follows: 


$$
\begin{gathered}
W P=Y / E T \\
I W P=Y / I W
\end{gathered}
$$

where Y: the economical yield $\left(\mathrm{kg} \mathrm{da}^{-1}\right)$; ET: the seasonal evapotranspiration $(\mathrm{mm})$; and I: the amount of seasonal irrigation water $(\mathrm{mm})$.

\section{Analysis and statistical evaluation}

Plant samples were taken to score the leaf area index (LAI) throughout the growing season at intervals of 10 days starting from the 31 st day of sowing in the first year (DAS), and at intervals of 12 days starting from DAS 38 in the second year. A portable leaf area meter was used for leaf area measurements (LI-COR 3100). In this study, 50 bolls were randomly selected from each plot. The seed cotton weight per boll, seed cotton yield, ginning turnout (based on Worley et al., 1976), fiber length, fiber fineness (micronaire), and fiber strength were scored using the methods specified in Anonymous (1997).

The results of the study were evaluated using Minitab 16 statistics software. First, analysis of variance (ANOVA) was performed to evaluate the effects of various irrigation treatments on the yield and quality of the cotton. The Tukey test was used for the mean grouping of the treatments.

\section{Result and discussions}

\section{Irrigation and crop evapotranspiration}

The amount of irrigation water applied according to the treatments, coupled with the seasonal crop evapotranspiration (ETc) of the treatments are given in Table 3.

Table 3. Amount of irrigation water and evapotranspiration for the treatments

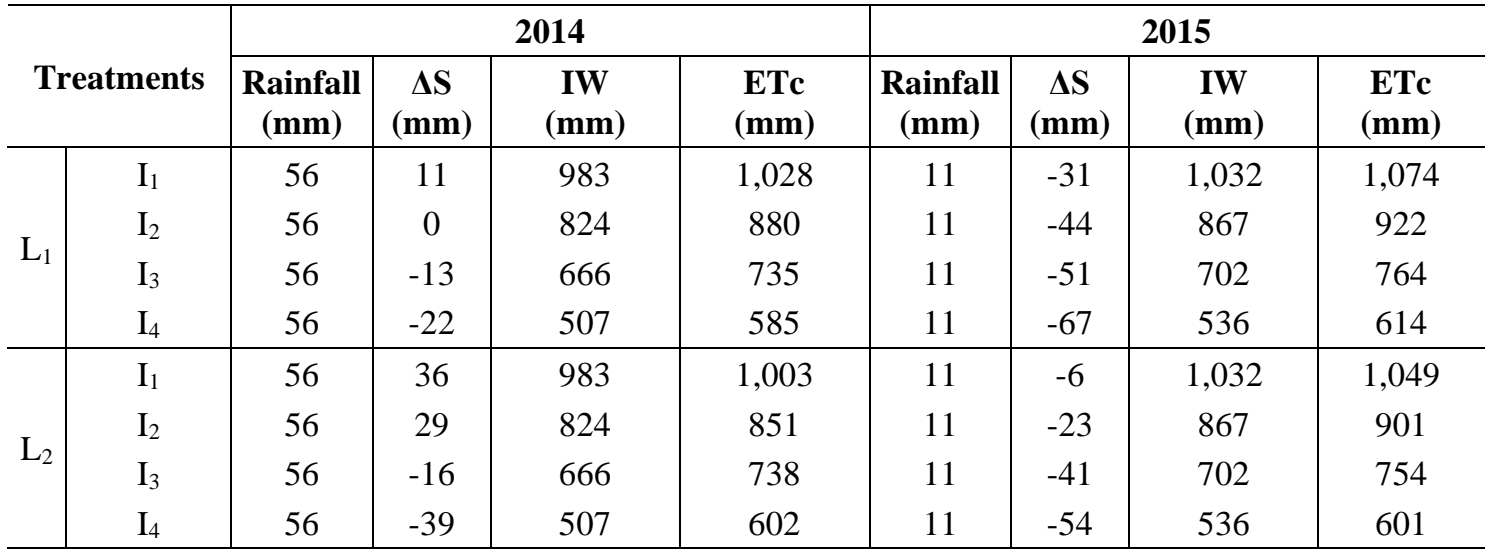

$\Delta \mathrm{S}$ : the change in the moisture content at a root depth of 0-90 cm, IW: Irrigation water, ETc: Seasonal crop evapotranspiration

Generally, almost the entire water requirement of the crop was met through irrigation, as no rainfall occurred during this period. However, excess spring precipitation in the late growing period delayed the initial irrigation, and thus, the irrigation water need decreased. The region's long-term annual precipitation average for 
the cotton growing period (May-September) was $30 \mathrm{~mm}$. During the first year of the experiment, it was $56 \mathrm{~mm}$, and during the second year, it was $11 \mathrm{~mm}$. Therefore, the plant's water need was fully met through irrigation.

Laterals were placed $0.70 \mathrm{~m}$ apart during $\mathrm{L}_{1}$ treatments. Meanwhile, irrigation was performed with the laterals spaced $1.40 \mathrm{~m}$ apart during $\mathrm{L}_{2}$ treatments. Therefore, the irrigation times for $L_{2}$ treatments were twice as long as those of $L_{1}$ treatments. During the first year of the field trial, the amount of irrigation water applied to the treatments varied between $507 \mathrm{~mm}$ and $983 \mathrm{~mm}$, and the amount was between 536 and $1032 \mathrm{~mm}$ during the second year. The water consumption associated with the trial treatments varied depending on the amount of irrigation water used. Treatments with less irrigation water benefited more from the moisture available in the soil at the time of sowing. Especially in the second year, all treatments utilized the moisture stored in the soil at different levels, whereas in the first year only, $\mathrm{I}_{4}$ and $\mathrm{I}_{3}$ treatments benefited from the moisture present at the time of planting. In addition, except for in the case of the $\mathrm{L}_{1}-\mathrm{I}_{2}$ treatments during the first year, it was observed that some of the irrigation water delivered during the treatments of $\mathrm{I}_{1}$ and $\mathrm{I}_{2}$ were stored in the soil.

\section{Seed cotton yield and some yield parameters}

ANOVA was performed for all scored characteristics and irrigation ratios, and the lateral spacing were found to be partially significant. The ANOVA table was not given here. However, the seed cotton yield and some of the yield factors during the experimental years are given in Table 4.

Table 4. Means and statistical groups for the seed cotton yield, boll seed cotton weight, and 100 seed weight values of cotton for the treatments

\begin{tabular}{c|c|c|c|c|c|c}
\hline \multirow{2}{*}{ Treatments } & \multicolumn{2}{|c|}{$\begin{array}{c}\text { Seed cotton yield } \\
\left(\mathbf{k g ~ d a}^{-1}\right)\end{array}$} & \multicolumn{2}{c|}{$\begin{array}{c}\text { Seed cotton weight } \\
(\mathbf{g} \text { boll-1 }\end{array}$} & \multicolumn{2}{c}{$\begin{array}{c}\text { 100 seed weights } \\
\text { (g) }\end{array}$} \\
\cline { 2 - 7 } & 2014 & 2015 & 2014 & 2015 & 2014 & 2015 \\
\hline $\mathrm{L}_{1}$ & 437.3 & $388.0 \mathrm{~b}$ & $4.18 \mathrm{~b}$ & 3.96 & 8.49 & 8.29 \\
$\mathrm{~L}_{2}$ & 468.5 & $432.8 \mathrm{a}$ & $4.36 \mathrm{a}$ & 4.02 & 8.45 & 8.36 \\
$\mathrm{P}($ Factor A) & $\mathrm{ns}$ & $*$ & $* * *$ & $\mathrm{~ns}$ & $\mathrm{~ns}$ & $\mathrm{~ns}$ \\
\hline $\mathrm{I}_{1}$ & $596.7 \mathrm{a}$ & $536.1 \mathrm{a}$ & $4.59 \mathrm{a}$ & $4.21 \mathrm{a}$ & 8.64 & $8.58 \mathrm{a}$ \\
$\mathrm{I}_{2}$ & $509.5 \mathrm{ab}$ & $463.2 \mathrm{a}$ & $4.40 \mathrm{~b}$ & $4.05 \mathrm{ab}$ & 8.41 & $8.48 \mathrm{ab}$ \\
$\mathrm{I}_{3}$ & $408.7 \mathrm{~b}$ & $371.8 \mathrm{~b}$ & $4.22 \mathrm{c}$ & $3.87 \mathrm{~b}$ & 8.42 & $8.15 \mathrm{~b}$ \\
$\mathrm{I}_{4}$ & $296.7 \mathrm{c}$ & $270.5 \mathrm{c}$ & $3.87 \mathrm{~d}$ & $3.82 \mathrm{~b}$ & 8.41 & $8.11 \mathrm{~b}$ \\
\hline $\mathrm{P}\left(\mathrm{Factor}_{2}\right)$ & $* *$ & $* *$ & $*$ & $* *$ & $\mathrm{~ns}$ & $* *$ \\
\hline $\mathrm{L}_{1}-\mathrm{I}_{1}$ & 577.0 & 522.3 & $4.50 \mathrm{ab}$ & 4.13 & 8.64 & 8.44 \\
$\mathrm{~L}_{1}-\mathrm{I}_{2}$ & 491.0 & 444.3 & $4.33 \mathrm{bcd}$ & 4.06 & 8.30 & 8.46 \\
$\mathrm{~L}_{1}-\mathrm{I}_{3}$ & 396.3 & 346.4 & $4.19 \mathrm{de}$ & 3.84 & 8.68 & 8.13 \\
$\mathrm{~L}_{1}-\mathrm{I}_{4}$ & 284.7 & 239.0 & $3.70 \mathrm{f} *$ & 3.81 & 8.34 & 8.15 \\
$\mathrm{~L}_{2}-\mathrm{I}_{1}$ & 616.3 & 549.8 & $4.68 \mathrm{a}$ & 4.29 & 8.64 & 8.72 \\
$\mathrm{~L}_{2}-\mathrm{I}_{2}$ & 528.0 & 482.1 & $4.46 \mathrm{bc}$ & 4.05 & 8.52 & 8.50 \\
$\mathrm{~L}_{2}-\mathrm{I}_{3}$ & 421.0 & 397.2 & $4.25 \mathrm{cde}$ & 3.90 & 8.15 & 8.17 \\
$\mathrm{~L}_{2}-\mathrm{I}_{4}$ & 308.7 & 302.0 & $4.04 \mathrm{e}$ & 3.83 & 8.49 & 8.06 \\
\hline $\left.\mathrm{P}_{(\mathrm{A}} * \mathrm{~B}\right)$ & $\mathrm{ns}$ & $\mathrm{ns}$ & $* *$ & $\mathrm{~ns}$ & $\mathrm{~ns}$ & $\mathrm{~ns}$ \\
\hline
\end{tabular}

$* *$ Significant at $1 \%, *$ significant at $5 \%$, ns: not significant

aThe treatments which have the same letter are not significantly different at the 5\% level by Tukey's test 
In this study, decreasing the amount of irrigation water resulted in a decrease in the cotton seed yield, and a statistically significant decrease in the yield was found. In the first year of the experiment, the seed cotton yields depended on the first two groups (Table 4). Both the drip line spacing $(\mathrm{p} \leq 0.05)$ and the water levels $(\mathrm{p} \leq 0.01)$ significantly affected the cotton yields in the second year. However, the effect of the main treatment and sub-treatment interaction was found to be nonsignificant. The yields in $\mathrm{L}_{2}$, where two plant rows were irrigated using a single drip line, was higher than that of $\mathrm{L}_{1}$. Although the yield of $\mathrm{L}_{2}$ was $31.2 \mathrm{~kg}$ more in the first year, it was statistically nonsignificant. However, in the second year, the yield of $\mathrm{L}_{2}$ was $44.8 \mathrm{~kg}$ more than that of $\mathrm{L}_{1}$, and this was found to be statistically significant.

In this study, seed cotton weights of 50 bolls that were randomly selected from each plot were averaged to score the seed cotton weights of the bolls used in the experimental treatments. The average boll cotton weights of the samples taken in the first year of the experiment varied between $3.70 \mathrm{~g}$ and $4.68 \mathrm{~g}$ depending on the treatment. It was found that the drip line spacing $(\mathrm{p} \leq 0.01)$, irrigation levels $(\mathrm{p} \leq 0.01)$, and interaction of both $(\mathrm{p} \leq 0.01)$ affected the boll cotton weight significantly. However, the irrigation of two plant rows from one lateral side had a positive effect on the boll seed cotton weight. Moreover, as the amount of irrigation water increased, the boll seed cotton weight increased. The highest seed cotton weight per boll was obtained from the treatment of $\mathrm{L}_{2}-\mathrm{I}_{1}$ with $4.68 \mathrm{~g}$, and this treatment ranked in the first group in the Tukey grouping.

The drip line spacing had no significant effect on the boll seed cotton weight in the second year. However, the irrigation levels significantly affected the boll seed cotton weight $(\mathrm{p} \leq 0.01)$. In this year, as the amount of irrigation water increased, the boll seed cotton weight increased, and the highest seed cotton yield per boll was obtained from the highest irrigation level $\left(I_{1}\right)$. The $I_{1}$ treatment ranked in the first group, and the $I_{4}$ and $\mathrm{I}_{3}$ treatments were in the last group.

In 2014, the 100 seed weights of the treatments varied between $8.15 \mathrm{~g}$ and $8.64 \mathrm{~g}$, but no significant difference arose from the factors. In the second year, although drip line spacing had no effect on the 100 seed weights, the effect of the amount of irrigation water used was significant $(\mathrm{p} \leq 0.01)$. As with other factors, irrigation had a positive effect on seed weight, and the highest of the 100 seed weights was obtained from the treatment with the highest water doses $(8.58 \mathrm{~g})$. This treatment alone ranked in the first Tukey grouping.

\section{Fiber quality parameters}

The effect of different lateral spacing and water amounts on the quality criteria of the cotton is given in Table 5 .

One of the most important quality criteria in cotton is fiber fineness. It is desirable for the fiber to be thin. In this study, the amounts of various irrigation doses in the first year had no effect on fiber fineness. In other words, reducing the amount of irrigation water did not have a positive or negative effect on fiber fineness. However, different drip line spacing amounts affected fiber fineness $(\mathrm{p} \leq 0.01)$. The single lateral irrigation of two plant rows increased fiber thickness, but the interaction of drip line spacing and irrigation level had no significant effect on fiber fineness. When the results of the second year were evaluated, no statistically significant differences were found among irrigation treatments for fiber fineness. Even though it was statistically nonsignificant, it was found that the fiber fineness decreased with the increase of the drip line spacing. This situation showed that the results of the first year might be coincidental. 
Table 5. Means and statistical groups for some fiber quality characteristics of treatments

\begin{tabular}{|c|c|c|c|c|c|c|c|c|}
\hline \multirow[t]{2}{*}{ Treatments } & \multicolumn{2}{|c|}{$\begin{array}{c}\text { Fiber fineness } \\
\text { micronaire }\end{array}$} & \multicolumn{2}{|c|}{$\begin{array}{l}\text { Fiber length } \\
(\mathrm{mm})\end{array}$} & \multicolumn{2}{|c|}{$\begin{array}{c}\text { Fiber strength } \\
\left(\mathrm{g} \mathrm{tex}^{-1}\right)\end{array}$} & \multicolumn{2}{|c|}{$\begin{array}{c}\text { Ginning outturn } \\
(\%)\end{array}$} \\
\hline & 2014 & 2015 & 2014 & 2015 & 2014 & 2015 & 2014 & 2015 \\
\hline $\mathrm{L}_{1}$ & $4.42 b$ & 4.72 & 27.6 & 26.8 & 28.4 & 27.4 & 42.4 & 41.2 \\
\hline $\mathrm{L}_{2}$ & $4.69 \mathrm{a}$ & 4.60 & 27.7 & 27.1 & 28.7 & 27.4 & 43.2 & 41.8 \\
\hline $\mathrm{P}($ Factor $\mathrm{A})$ & $* *$ & $\mathrm{~ns}$ & $\mathrm{~ns}$ & $\mathrm{~ns}$ & ns & $\mathrm{ns}$ & $\mathrm{ns}$ & $\mathrm{ns}$ \\
\hline $\mathrm{I}_{1}$ & 4.65 & 4.70 & 27.8 & 26.9 & 28.1 & 27.7 & $48.2 \mathrm{a}$ & $45.1 \mathrm{a}$ \\
\hline $\mathrm{I}_{2}$ & 4.50 & 4.57 & 27.5 & 27.0 & 28.5 & 26.8 & $42.7 b$ & $42.3 \mathrm{ab}$ \\
\hline $\mathrm{I}_{3}$ & 4.70 & 4.68 & 27.5 & 26.5 & 28.8 & 26.8 & $41.2 \mathrm{~b}$ & $40.2 \mathrm{bc}$ \\
\hline $\mathrm{I}_{4}$ & 4.38 & 4.69 & 27.6 & 27.3 & 28.8 & 28.1 & $39.0 \mathrm{c}$ & $38.4 \mathrm{c}$ \\
\hline $\mathrm{P}$ (Factor B) & ns & $\mathrm{ns}$ & $\mathrm{ns}$ & $\mathrm{ns}$ & $\mathrm{ns}$ & $\mathrm{ns}$ & $* *$ & $* *$ \\
\hline $\mathrm{L}_{1}-\mathrm{I}_{1}$ & 4.42 & 4.72 & 27.7 & 27.0 & 28.4 & 27.4 & 47.8 & 44.7 \\
\hline $\mathrm{L}_{1}-\mathrm{I}_{2}$ & 4.45 & 4.68 & 27.3 & 27.2 & 28.7 & 27.2 & 42.1 & 41.9 \\
\hline $\mathrm{L}_{1}-\mathrm{I}_{3}$ & 4.64 & 4.80 & 27.7 & 26.1 & 28.4 & 26.7 & 41.0 & 40.3 \\
\hline $\mathrm{L}_{1}-\mathrm{I}_{4}$ & 4.18 & 4.68 & 27.6 & 26.9 & 28.2 & 28.3 & 38.6 & 37.9 \\
\hline $\mathrm{L}_{2}-\mathrm{I}_{1}$ & 4.88 & 4.67 & 27.9 & 26.9 & 27.8 & 28.0 & 48.6 & 45.5 \\
\hline $\mathrm{L}_{2}-\mathrm{I}_{2}$ & 4.54 & 4.47 & 27.7 & 26.9 & 28.4 & 26.5 & 43.3 & 42.8 \\
\hline $\mathrm{L}_{2}-\mathrm{I}_{3}$ & 4.76 & 4.56 & 27.4 & 26.8 & 29.2 & 27.0 & 41.4 & 40.1 \\
\hline $\mathrm{L}_{2}-\mathrm{I}_{4}$ & 4.58 & 4.71 & 27.6 & 27.7 & 29.4 & 28.0 & 39.4 & 38.9 \\
\hline $\mathrm{P}(\mathrm{A} * \mathrm{~B})$ & ns & $\mathrm{ns}$ & $\mathrm{ns}$ & $\mathrm{ns}$ & $\mathrm{ns}$ & $\mathrm{ns}$ & $\mathrm{ns}$ & $\mathrm{ns}$ \\
\hline
\end{tabular}

$* *$ Significant at $1 \%, *$ significant at $5 \%$, ns: not significant

${ }^{a}$ The treatments which have the same letter are not significantly different at the 5\% level by Tukey's test

Similar results were also found for fiber strength. Although the strength values varied between 27.8 and $29.4 \mathrm{~g}^{-1} \mathrm{x}^{-1}$ in the first year and between 26.5 and $28.3 \mathrm{~g}^{-1}$ in the second year, these fluctuations between the treatments were not statistically significant.

The results obtained from this study revealed that the drip line spacing during both years of the field trial had no effect on the yield. Again, the interaction between the main plots and subplots did not have any significant effect on ginning efficiency. However, the irrigation levels significantly affected the yield in both years $(p \leq 0.01)$. As the irrigation doses increased, the ginning efficiency also increased up to $48.2 \%$ in the first year and $45.1 \%$ in the second year for the highest amount of irrigation $\left(\mathrm{I}_{1}\right)$. However, in the $\mathrm{I}_{4}$ treatments, these values remained at $39 \%$ and $38.4 \%$, respectively. In previous studies, some conflicting results between irrigation water doses versus ginning efficiency have been revealed.

\section{Leaf area index and water use efficiencies}

The LAI was determined by taking plant samples at regular intervals during the plant growing season. In Figure 1, LAI variations for the consecutive years are given.

When the temporal variation of the LAI results of trial treatments was examined, a sigmoidal relationship was found between the LAIs and times in both years. The LAI started to increase when the plants began to emerge, and it continued until approximately 100-110 days after sowing (DAS), at which point it reached its maximum level. Although the LAIs of all treatments increased continuously during this period, the LAI values of the treatments started to differ with the initiation of irrigation 
at different doses. The negative effects of water stress on the LAI began to be observed with the start of the irrigation practices used in the treatments. Since DAS 60, the differentiation in the LAI values regarding the applications has occurred distinctly (Fig. 1). As the amount of irrigation water increased, the LAI increased more quickly, and the $\mathrm{I}_{1}$ treatments reached the highest values in both years. The LAI indices decreased after DAS 110 until the harvest. The LAI values of the fully irrigated $\mathrm{L}_{1}-\mathrm{I}_{1}$ and $\mathrm{L}_{2}-\mathrm{I}_{1}$ treatments reached 4.83 and 5.16 in the first year, and 5.00 and 5.07 in the second year, respectively.

The highest LAI value was obtained from the full irrigation treatment. However, these studies showed variations in the amount of time required to reach the highest LAI. As mentioned above, the employed agricultural techniques, environment, and cotton varieties played an important role in this situation.

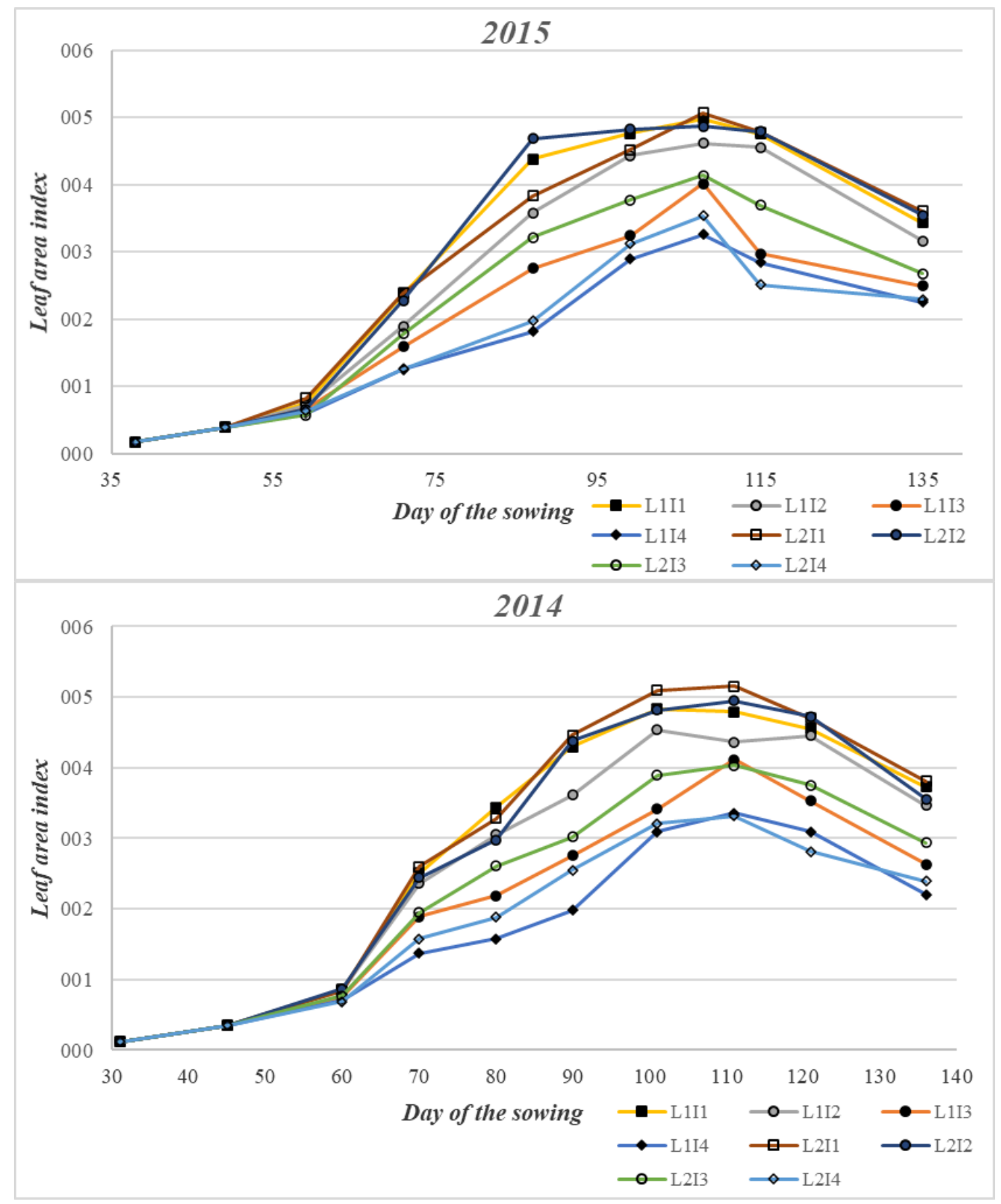

Figure 1. Temporal changes in leaf area index 
Water productivity is an important indicator in determining the most suitable irrigation program in restricted irrigation studies. The WP and IWP values were calculated for this study and are given in Figure 2.

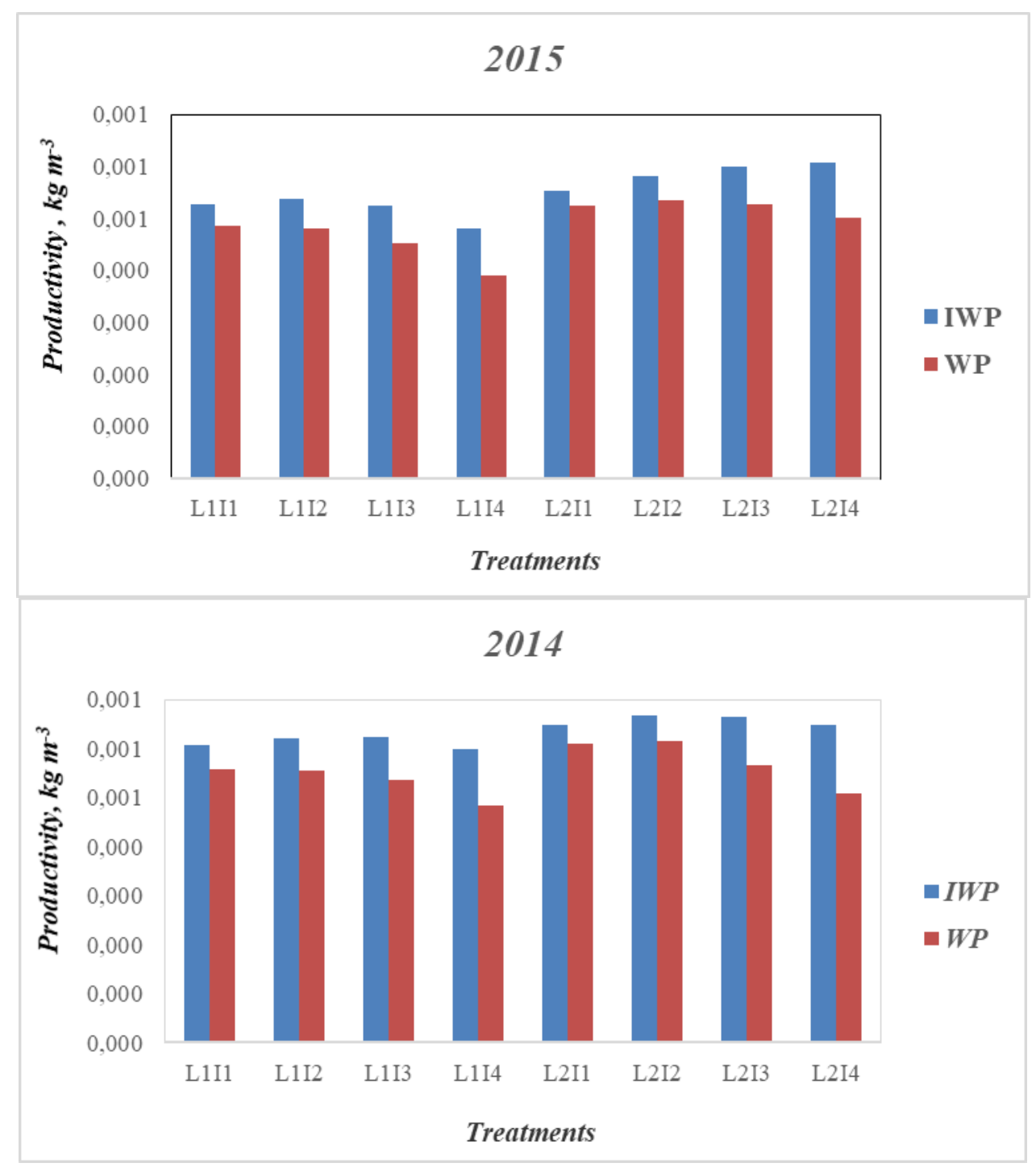

Figure 2. Water productivity and irrigation water production for the treatments

The IWP values varied between $0.60 \mathrm{~kg} \mathrm{~m}^{-3}$ and $0.67 \mathrm{~kg} \mathrm{~m}^{-3}$ in the first year and between $0.48 \mathrm{~kg} \mathrm{~m}^{-3}$ and $0.61 \mathrm{~kg} \mathrm{~m}^{-3}$ in the second year.

In the first year, the IWP values did not differ significantly depending on the amount of irrigation water doses used, but the IWP values of the $\mathrm{L}_{2}$ treatments were higher than those of the $\mathrm{L}_{1}$ treatments in the same irrigation treatments. Although the same amount of irrigation water was applied, the more effective use of irrigation water in the $140-\mathrm{cm}$ lateral range was due to the lower evaporation losses in this lateral range. Similar results were obtained in the second year, whereas higher WP irr values were obtained from the $\mathrm{L}_{2}$ treatments. However, no obvious differences were found due to the irrigation levels.

The WP values were lower than the IWP values were. These values varied between $0.48 \mathrm{~kg} \mathrm{~m}^{-3}$ and $0.61 \mathrm{~kg} \mathrm{~m}^{-3}$ in the first year and decreased to 0.39 for $\mathrm{L}_{1}-\mathrm{I}_{4}$, which was 
scored even lower in the second year. At the same time, the differences among the IWP values of the second year were more pronounced. In both years, the lowest WP values were obtained from the $\mathrm{L}_{1}-\mathrm{I}_{4}$ treatments. This was due to the proportionally higher amount of evaporation in the ET. When drip line spaces were evaluated, the WPs of the $\mathrm{L}_{2}$ treatments were higher than those of the $\mathrm{L}_{1}$ treatments. In this case, the wetted zone in the $\mathrm{L}_{2}$ treatments consisted of a narrow yet deep profile. The low wetted soil surface caused the amount of water that entered the atmosphere through evaporation to be lower, considering the very hot and low relative humidity conditions of the region.

\section{Discussion}

In the study, the highest yield was found to be full irrigation treatment. During the cotton growing period, the region was very hot, and the relative humidity was also low, thus requiring intensive irrigation in cotton as pointed out by Chapagain et al. (2006) and Darouich et al. (2014). Some researchers also obtained similar results for semi-arid regions (Karam et al., 2006; DeTar, 2008; Onder et al., 2009; Singh et al., 2010; Ünlü et al., 2011). In addition, the factors of relative humidity, temperature, radiation and wind speed played an important role in plant water consumption (Rao et al., 2016). Therefore, in arid climates, the plant water consumption was higher than that of semi-arid climate. The amount of water consumption obtained from the study confirmed the research findings of Tüzel and Ul (2003) and Hunsaker et al. (2015).

The lateral spacing of 70 and $140 \mathrm{~cm}$ did not affect the ETc values significantly. The highest water consumption level occurred in L1-I1 factor in both years. Although no significant difference was found among the water consumption levels of the main treatments, the water consumption levels of the L1-I1 and L1-I2 treatments were relatively higher than those of the L2-I1 and L2-I2 treatments. This resulted in that the evaporation losses were high due to the double wetted surface area resulting from the lateral laying of each row in L1.

Although the same amount of irrigation water was given to plots, the main reason for the higher yield in L2 $(140 \mathrm{~cm})$ comparing L1 $(70 \mathrm{~cm})$ could be explained by the different amounts of evaporation loss among the main treatments. Although more evaporation was observed in L1 comparing in L2, the percentage of wetted area in L1 was higher than that of L2. This can be attributed totally the climatic condition in the experimental region (hot and featuring very low relative humidity). Similar results were also obtained in another study conducted earlier (Sar1, 2010).

The highest seed cotton yields were obtained by the factor without any water restrictions (I1). The yield obtained from this treatment was similar to that of Yang et al. (2015) and Zhang et al. (2016). However, the yields obtained by our study were higher than those of some other studies (Yavuz, 1993; Ertek and Kanber, 2001; Cetin and Bilgel, 2002; Onder et al., 2009; Çetin and Kara, 2019; Chen et al., 2020). These differences could be derived from the climate, soil characteristics, cotton variety, and cultivation techniques of the research sites. In terms of boll seed cotton yield, the findings on the boll seed cotton weight were similar to those of previous studies (Pettigrew, 2004; Rao et al., 2016). Moreover, in previous studies it was stated that the increasing amount of irrigation water also increased the weight of the 100 grains (Dagdelen et al., 2009a; Sari and Dagdelen, 2010)

Fiber quality also was affected by the factors implemented in our study. The fiber fineness values obtained from the experiment were higher than those of the conditions 
obtained in similar climatic conditions (Thorp et al., 2020). This difference may be due to the characteristics of the cultivar. Lateral spacing or water limitation did not affect fiber fineness. Other studies on water restriction in cotton have also reported that water restriction had no effect on fiber fineness (Karam et al., 2006; Dagdelen et al., 2009b; Ünlü et al., 2011; Papastylianou and Argyrokastritis, 2014). Fiber length was another important quality criterion in cotton. Practicing various factors in both years of this study had no effect on fiber length. At the same time, irrigation factors with different lateral spacings did not affect fiber length either positively or negatively. Contrary to the results in this study, Thorp et al. (2020) reported that water restriction reduced the short fiber content. The research findings in this study were mostly confirmed by other researchers (Ünlü et al., 2011; Papastylianou and Argyrokastritis, 2014). The water shortages or limitations in the lateral range had also no effect on the fiber strength, which showed nonsignificant differences between the drip line spacing and irrigation doses. Our results were in agreement with those of Karam et al. (2006), Booker et al. (2006), Ünlü et al. (2011) and Papastylianou and Argyrokastritis (2014). Sari (2010) also confirmed our findings, whereas Dagdelen et al. (2009b) stated that irrigation water did not affect the ginning turnout. Onder et al. (2009) furthermore stated that the increase in irrigation water decreased the ginning efficiency. The most important reason for these variations was the characteristics of the varieties used in the experiments, as well as many other factors, such as climate and agricultural practices.

Although LAI varied due to applied agricultural techniques, the environment, and the cotton variety That of full irrigation were in accordance with the results of previous studies (Stone et al., 2001; Yazar et al., 2002; Karam et al., 2006; Kang et al., 2012; Sampathkumar et al., 2013).

WP and IWP values of irrigation increase in arid regions. In these regions, almost no rainfall occurs during the cotton growing period. Furthermore, the plant water consumption increases to a level higher than in other climatical conditions. In previous studies, some researchers stated that WP and IWP increased with water restriction (Ünlü et al., 2011; Yang et al., 2015; Fan et al., 2018; Garibay et al., 2019). However, some researchers reported confirming our finding that no significant effect occurred in WP and IWP due to water shortages (Chen et al., 2020).

\section{Conclusion}

The widespread adoption of limitations in irrigation water in arid regions throughout the entire growing season resulted in significant decreases in the cotton yield. Therefore, if limited irrigation operations are to be practiced, the water sensitivity of plant growth periods should be taken into account, and irrigation should be limited when cotton is insensitive to water. The reduction of irrigation water on quality did not have such a severe effect on the yield, and even some quality criteria were never affected by the amount of irrigation water.

In addition, in drip irrigation, irrigation of two rows instead single row from only one lateral resulted in higher yielding contrary to low yield expect. Decreasing the number of lateral spaces by half caused the wetted area to decrease at the same rate. This was derived from a decrease in evaporation losses from the soil. This situation also caused the IWP and WP values to be higher in the wide drip line spacing than in the narrow ones. 
The adoption of drip line spacing in areas where soil conditions are suitable for instance, soils with high water usage productivity will also reduce the lateral space related expense of the irrigation system by half. This is another important advantage of this system.

Acknowledgments. This work was financially supported by the Harran University Application and Research Center for Science and Technology, (Project number: 14051).

\section{REFERENCES}

[1] Anonymous (1997): High volume instruments (HVI) catalog. - Costumer Inf Serv No 40, Vol May, Sweden.

[2] Bilalis, D., Patsiali, S., Karkanis, A., Konstantas, A., Makris, M., Efthimiadou, A. (2010): Effects of cultural system (organic and conventional) on growth and fiber quality of two cotton (Gossypium hirsutum L.) varieties. - Renewable Agriculture and Food Systems 25(3): 228-235. https://doi.org/10.1017/S1742170510000190.

[3] Bölük, E. (2016): Aydeniz İklim Siniflandirmasina Göre Türkiye İklimi. - Turkish State.

[4] Booker, J. D., Bordovsky, J., Lascano, R. J., Segarra, E. (2006): Variable rate irrigation on cotton lint yield and fiber quality. - Beltwide Cotton Conferences, San Antonio, Texas. January 3-6, 2006.

[5] Cai, H., Shao, G., Zhang, Z. (2002): Lateral layout of drip irrigation under plastic mulch for cotton. - Trans CSAE 18(1): 45-48.

[6] Campbell, B. T., Jones, M. A. (2005): Assessment of genotype X environment interactions for yield and fiber quality in cotton performance trials. - Euphytica 144(1-2): 69-78.

[7] Çetin, Ö., Akalp, E. (2019): Efficient use of water and fertilizers in irrigated agriculture: drip irrigation and fertigation. - Acta Horticulturae et Regiotecturae 22(2): 97-102. https://doi.org/10.2478/ahr-2019-0019.

[8] Cetin, O., Bilgel, L. (2002): Effects of different irrigation methods on shedding and yield of cotton. - Agricultural Water Management 54(1): 1-15. https://doi.org/10.1016/S03783774(01)00138-X.

[9] Çetin, O., Kara, A. (2019): Assessment of water productivity using different drip irrigation systems for cotton. - Agricultural Water Management 223: 105693. https://doi.org/10.1016/j.agwat.2019.105693.

[10] Chapagain, A. K., Hoekstra, A. Y., Savenije, H. H. G., Gautam, R. (2006): The water footprint of cotton consumption: an assessment of the impact of worldwide consumption of cotton products on the water resources in the cotton producing countries. - Ecological Economics 60(1): 186-203. https://doi.org/10.1016/j.ecolecon.2005.11.027.

[11] Chen, X., Qi, Z., Gui, D., Sima, M. W., Zeng, F., Li, L., Li, X., Gu, Z. (2020): Evaluation of a new irrigation decision support system in improving cotton yield and water productivity in an arid climate. - Agricultural Water Management 234: 106139. https://doi.org/10.1016/j.agwat.2020.106139.

[12] Dağdelen, N., Başal, H., Yılmaz, E., Gürbüz, T., Akçay, S. (2009a): Different drip irrigation regimes affect cotton yield, water use efficiency and fiber quality in western Turkey. - Agricultural Water Management 96(1): 111-120. https://doi.org/10.1016/j.agwat.2008.07.003.

[13] Dağdelen, N., Sezgin, F., Gürbüz, T., Yılmaz, E., Akçay, S. (2009b): Effects of different irrigation intervals and levels on fiber quality and some yield characteristics of cotton. Adnan Menderes Univ Fac Agric J. 6(1): 53-61.

[14] Darouich, H. M., Pedras, C. M. G., Gonçalves, J. M., Pereira, L. S. (2014): Drip vs. surface irrigation: a comparison focussing on water saving and economic returns using 
multicriteria analysis applied to cotton. - Biosystems Engineering 122: 74-90. https://doi.org/10.1016/j.biosystemseng.2014.03.010.

[15] DeTar, W. R. (2008): Yield and growth characteristics for cotton under various irrigation regimes on sandy soil. - Agricultural Water Management 95(1): 69-76. https://doi.org/10.1016/j.agwat.2007.08.009.

[16] Ertek, A., Kanber, R. (2001): Effects of different irrigation programs on the growth of cotton under drip irrigation. - Turkish Journal of Agriculture and Forestry 25(6): 415425.

[17] Fan, Y., Wang, C., Nan, Z. (2018): Determining water use efficiency of wheat and cotton: a meta-regression analysis. - Agricultural Water Management 199: 48-60. https://doi.org/10.1016/j.agwat.2017.12.006.

[18] Garibay, V. M., Kothari, K., Ale, S., Gitz, D. C., Morgan, G. D., Munster, C. L. (2019): Determining water-use-efficient irrigation strategies for cotton using the DSSAT CSM CROPGRO-cotton model evaluated with in-season data. - Agricultural Water Management 223: 105695. https://doi.org/10.1016/j.agwat.2019.105695.

[19] Gerik, T. J., Faver, K. L., Thaxton, P. M., El-Zik, K. M. (1996): Late season water stress in cotton: I. Plant growth, water use, and yield. - Crop Sci. 36(4): 914-921. https://doi.org/10.2135/cropsci1996.0011183X003600040017x.

[20] Guo, D. P., Sun, Y. Z. (2001): Estimation of leaf area of stem lettuce (Lactuca sativa var angustana) from linear measurements. - Indian Journal of Agricultural Sciences 71(7): 483-486.

[21] Hunsaker, D. J., French, A. N., Waller, P. M., Bautista, E., Thorp, K. R., Bronson, K. F., Andrade-Sanchez, P. (2015): Comparison of traditional and ET-based irrigation scheduling of surface-irrigated cotton in the arid southwestern USA. - Agricultural Water Management 159: 209-224. https://doi.org/10.1016/j.agwat.2015.06.016.

[22] Ibragimov, N., Evett, S. R., Esanbekov, Y., Kamilov, B. S., Mirzaev, L., Lamers, J. P. A. (2007): Water use efficiency of irrigated cotton in Uzbekistan under drip and furrow irrigation. - Agricultural Water Management 90(1-2): 112-120. https://doi.org/10.1016/j.agwat.2007.01.016.

[23] James, L. G. (1988): Principles of Farm Irrigation Systems Design. - John Wiley and Sons, Hoboken, NJ.

[24] Kang, Y., Wang, R., Wan, S., Hu, W., Jiang, S., Liu, S. (2012): Effects of different water levels on cotton growth and water use through drip irrigation in an arid region with saline ground water of Northwest China. - Agricultural Water Management 109: 117-126. https://doi.org/10.1016/j.agwat.2012.02.013.

[25] Karam, F., Lahoud, R., Masaad, R., Daccache, A., Mounzer, O., Rouphael, Y. (2006): Water use and lint yield response of drip irrigated cotton to the length of irrigation season. - Agricultural Water Management 85(3): 287-295. https://doi.org/10.1016/j.agwat.2006.05.003.

[26] Katerji, N., Mastrorilli, M., Rana, G. (2008): Water use efficiency of crops cultivated in the Mediterranean region: review and analysis. - European Journal of Agronomy 28(4): 493-507. https://doi.org/10.1016/j.eja.2007.12.003.

[27] Keller, J., Bliesner, R. D. (1990): Sprinkle and Trickle Irrigation. - Chapman and Hall, New York.

[28] Longnecker, N. (1994): Nutrient Deficiencies and Vegetative Growth. - In: Basra, A. S. (ed.) Mechanisms of Plant Growth and Improved Productivity: Modern Approaches and Perspectives. Marcel Dekker, New York, pp. 137-172.

[29] Mert, M. (2005): Irrigation of cotton cultivars improves seed cotton yield, yield components and fibre properties in the Hatay region, Turkey. - Acta Agric Scand Sect B Soil Plant Sci. 55(1): 44-50. https://doi.org/10.1080/09064710510008658.

[30] Onder, D., Akiscan, Y., Onder, S., Mert, M. (2009): Effect of different irrigation water level on cotton yield and yield components. - African Journal of Biotechnology 8(8): $1536-1544$. 
[31] Papastylianou, P. T., Argyrokastritis, I. G. (2014): Effect of limited drip irrigation regime on yield, yield components, and fiber quality of cotton under Mediterranean conditions. $\begin{array}{llll}\text { Agricultural Water } & \text { 127-134. }\end{array}$ https://doi.org/10.1016/j.agwat.2014.05.005.

[32] Pereira, L. S., Cordery, I., Iacovides, I. (2012): Improved indicators of water use performance and productivity for sustainable water conservation and saving. Agricultural Water Management 108: 39-51. https://doi.org/10.1016/j.agwat.2011.08.022.

[33] Pettigrew, W. T. (2004): Moisture deficit effects on cotton lint yield, yield components, and boll distribution. - Agron J. 96(2): 377-383. https://doi.org/10.2134/agronj2004.3770.

[34] Rao, S. S., Tanwar, S. P. S., Regar, P. L. (2016): Effect of deficit irrigation, phosphorous inoculation and cycocel spray on root growth, seed cotton yield and water productivity of drip irrigated cotton in arid environment. - Agricultural Water Management 169: 14-25. https://doi.org/10.1016/j.agwat.2016.02.008.

[35] Sampathkumar, T., Pandian, B. J., Rangaswamy, M. V., Manickasundaram, P., Jeyakumar, P. (2013): Influence of deficit irrigation on growth, yield and yield parameters of cotton-maize cropping sequence. - Agricultural Water Management 130: 90-102. https://doi.org/10.1016/j.agwat.2013.08.018.

[36] Sarı, Ö. (2010): A research on Determination of Effects of Different Lateral Spacing and Irrigation Programme for Drip Irrigated Cotton in Aydin Province. - Adnan Menderes University, Aydin.

[37] Sari, Ö., Dağdelen, N. (2010): Effects of different lateral spacing on fiber quality and some yield characteristics of drip irrigated cotton. - Adnan Menderes University Faculty of Agriculture Journal 7(2): 49-55.

[38] Singh, Y., Rao, S. S., Regar, P. L. (2010): Deficit irrigation and nitrogen effects on seed cotton yield, water productivity and yield response factor in shallow soils of semi-arid environment. - Agricultural Water Management 97(7): 965-970. https://doi.org/10.1016/j.agwat.2010.01.028.

[39] Steduto, P., Faurès, J. M., Hoogeveen, J., Winpenny, J., Burke, J. (2012): Coping with Water Scarcity: An Action Framework for Agriculture and Food Security. - Food and Agriculture Organization of the United Nations, Rome.

[40] Stone, P. J., Wilson, D. R., Jamieson, P. D., Gillespie, R. N. (2001): Water deficit effects on sweet corn. II. Canopy development. - Australian Journal of Agricultural Research 52: 115-126. https://doi.org/10.1071/AR99145.

[41] Thorp, K. R., Thompson, A. L., Bronson, K. F. (2020): Irrigation rate and timing effects on Arizona cotton yield, water productivity, and fiber quality. - Agricultural Water Management 234: 106146. https://doi.org/10.1016/j.agwat.2020.106146.

[42] Tüzel, I. H., Ul, M. A. (2003): Pamuk sulaması. - Pamukta Eğitim Semineri, 14-17 Ekim 2003, İzmir, pp. 83-92.

[43] Ünlü, M., Kanber, R., Koç, D. L., Tekin, S., Kapur, B. (2011): Effects of deficit irrigation on the yield and yield components of drip irrigated cotton in a Mediterranean environment. - Agricultural Water Management 98(4): 597-605. https://doi.org/10.1016/j.agwat.2010.10.020.

[44] USSL (1954): Diagnosis and improvement of saline and alkaline soils. - Soil Sci Soc Am J. 18(3): 348

[45] Wilde, C., Johnson, J., Bordovsky, J. P. (2009): Economic analysis of subsurface drip irrigation system uniformity. - Applied Engineering in Agriculture 25(3): 357-362.

[46] Worley, S., Ramey, H. H., Harrell, D. C., Culp, T. W. (1976): Ontogenetic model of $\begin{array}{llllll}\text { cotton yield. } & - & \text { Crop } & \text { Science }\end{array}$ https://doi.org/10.2135/cropsci1976.0011183X001600010008x.

[47] Yang, C., Luo, Y., Sun, L., Wu, N. (2015): Effect of deficit irrigation on the growth, water use characteristics and yield of cotton in arid Northwest China. - Pedosphere 25(6): 910-924. https://doi.org/10.1016/S1002-0160(15)30071-0. 
[48] Yavuz, M. Y. (1993): The Effects of Different Irrigation Methods on the Yield and Water Use Efficiencies of Cotton. - Cukurova University, Adana.

[49] Yazar, A., Sezen, S. M., Sesveren, S. (2002): LEPA and trickle irrigation of cotton in the Southeast Anatolia Project (GAP) area in Turkey. - Agricultural Water Management 54(3): 189-203. https://doi.org/10.1016/S0378-3774(01)00179-2.

[50] Zhang, D., Luo, Z., Liu, S., Li, W., Wei Tang Dong, H. (2016): Effects of deficit irrigation and plant density on the growth, yield and fiber quality of irrigated cotton. Field Crops Research 197: 1-9. https://doi.org/10.1016/j.fcr.2016.06.003. 